\title{
A Phytoplasma Closely Related to the Pigeon Pea Witches'-Broom Phytoplasma (16Sr IX) Is Associated with Citrus Huanglongbing Symptoms in the State of São Paulo, Brazil
}

\author{
D. C. Teixeira, N. A. Wulff, E. C. Martins, E. W. Kitajima, R. Bassanezi, A. J. Ayres, \\ S. Eveillard, C. Saillard, and J. M. Bové
}

First, second, third, fifth, and sixth authors: Fundecitrus, Araraquara, SP, CEP 14807-040, Brazil; fourth author: Universidade de São Paulo, CEP 13418-900, Piracicaba, SP, Brazil; and seventh, eighth, and ninth authors: Institut National de la Recherche Agronomique and Université de Bordeaux 2, UMR 1090, BP 81, 33883 Villenave d'Ornon, France. Accepted for publication 14 May 2008.

\begin{abstract}
Teixeira, D. C., Wulff, N. A., Martins, E. C., Kitajima, E. W., Bassanezi, R., Ayres, A. J., Eveillard, S., Saillard, C., and Bové, J. M. 2008. A phytoplasma closely related to the pigeon pea witches'-broom phytoplasma (16Sr IX) is associated with citrus huanglongbing symptoms in the state of São Paulo, Brazil. Phytopathology 98:977-984.

In February 2007, sweet orange trees with characteristic symptoms of huanglongbing (HLB) were encountered in a region of São Paulo state (SPs) hitherto free of HLB. These trees tested negative for the three liberibacter species associated with HLB. A polymerase chain reaction (PCR) product from symptomatic fruit columella DNA amplifications with universal primers $\mathrm{fD} 1 / \mathrm{rP} 1$ was cloned and sequenced. The corresponding agent was found to have highest $16 \mathrm{~S}$ rDNA sequence identity

primer pairs fU5/rU3, fU5/P7 confirm these results. With two primers $\mathrm{D} 7 \mathrm{f} 2 / \mathrm{D} 7 \mathrm{r} 2$ designed based on the $16 \mathrm{~S}$ rDNA sequence of the cloned DNA fragment, positive amplifications were obtained from more than one hundred samples including symptomatic fruits and blotchy mottle leaves. Samples positive for phytoplasmas were negative for liberibacters, except for four samples, which were positive for both the phytoplasma and 'Candidatus Liberibacter asiaticus'. The phytoplasma was detected by electron microscopy in the sieve tubes of midribs from symptomatic leaves. These results show that a phytoplasma of group IX is associated with citrus HLB symptoms in northern, central, and southern SPs. This phytoplasma has very probably been transmitted to citrus from an external source of inoculum, but the putative insect vector is not yet known.
\end{abstract} (99\%) with the pigeon pea witches'-broom phytoplasma of group $16 \mathrm{Sr}$ IX. Sequences of PCR products obtained with phytoplasma 16S rDNA
Additional keywords: PCR detection, plant-pathogenic mollicute.
Huanglongbing (HLB) or yellow shoot disease of citrus, known in China since the late 19th century and in South Africa since 1928, was found in 2004 in the State of São Paulo, Brazil, and in 2005 in Florida, United State, two major citrus growing regions, where the disease endangers the very existence of commercial citrus $(4,9,10,17)$. On leaves, a most characteristic HLB symptom is blotchy mottle, while symptomatic fruits are lopsided and show abnormal coloration; seeds are aborted and brownish, and vascular bundles at the peduncular end of the fruit axis (columella) are stained brown. Prior to 2004, only two HLB agents were known: 'Candidatus Liberibacter asiaticus' in Asia, and 'Candidatus Liberibacter africanus' in Africa. The liberibacters are endogenous, noncultured, sieve tube restricted alpha-proteobacteria $(22,24)$. They are best seen by electron microscopy in the sieve tubes from leaf midribs or in the brownish stained vascular bundles in the fruit columella. Two citrus psyllids are responsible for the rapid spread of the liberibacters from citrus to citrus: Diaphorina citri in Asia and Trioza erytreae in Africa. PCR primers became available for the detection of the two liberibacters by amplification of their $16 \mathrm{~S}$ ribosomal DNA (16S rDNA) in 1996 (23), and by amplification of ribosomal protein genes in 1999 (21). These liberibacter-specific primers were used successfully in many Asian and African countries to identify and confirm

Corresponding author: C. Saillard; E-mail address: saillard@ bordeaux.inra.fr

doi:10.1094/PHYTO-98-9-0977

() 2008 The American Phytopathological Society the presence of HLB (12-15). Surprisingly, when they were used in 2004 in São Paulo state (SPs) to assess the presence of the liberibacters in blotchy mottle leaf samples from sweet orange trees showing characteristic HLB symptoms, only 2 of 108 samples tested positive for ' $\mathrm{Ca}$. L. asiaticus', while the remaining 106 samples tested negative (33). Search for a new HLBassociated agent in blotchy mottle leaves by amplification of $16 \mathrm{~S}$ rDNA with universal bacterial primers was initiated, and resulted in the discovery of 'Candidatus Liberibacter americanus', a new liberibacter species $(34,35)$. Primers specific to the new species were designed and were able to detect the American liberibacter not only in the 106 samples previously negative, but also in the majority of HLB-affected citrus trees in São Paulo state (SPs) (33), the remaining trees being infected with ' $\mathrm{Ca}$. L. asiaticus' (7). As of November 2007 and on the basis of blotchy mottle leaf samples, the presence of ' $\mathrm{Ca}$. L. americanus' alone has been assessed in 45 municipalities of SPs, ' $C a$. L. asiaticus' being present alone in seven municipalities, and 66 municipalities harboring both liberibacters. One municipality in the state of Parana carries ' $\mathrm{Ca}$. L. asiaticus', and one municipality in the state of Minas Gerais is affected by ' $\mathrm{Ca}$. L. americanus'. The Asian citrus psyllid, D. citri, present in SPs since the 1940s, is responsible for the spread of ' $C a$. L. asiaticus' as well as ' $C a$. L. americanus' in SPs (38), and also it transmits ' $\mathrm{Ca}$. L. asiaticus' in Florida, where it has been present since $1998(19,20)$.

In February 2007, HLB-affected trees, with characteristic blotchy mottle leaves and lopsided fruits carrying aborted seeds and having brownish vascular bundles in their columellae, were found in the Barretos and Colômbia municipalities of northern 
SPs, a region hitherto free of HLB. Unexpectedly, blotchy mottle leaf samples from these trees gave negative PCR tests for all three liberibacter species, a situation reminiscent of that encountered in 2004. Hence, DNA samples from blotchy mottle leaves and symptomatic fruits were used to amplify, with universal bacterial PCR primers, the 16S rDNA of a putative new agent associated with HLB. As shown in this paper, the amplified DNA was found to correspond to a phytoplasma having 99\% 16S rDNA sequence identity with the pigeon pea witches'-broom phytoplasma (16Sr IX). Sweet orange trees infected with the phytoplasma show leaf and fruit symptoms indistinguishable from those produced by the liberibacters. Besides sugar beet $(16,29)$ and strawberry $(11,31)$, citrus is the third host in which a phytoplasma and a proteobacterium can cause identical symptoms in the same plant. The origin of the phytoplasma in SPs and the consequences of a phytoplasma being involved in HLB in SPs are discussed.

\section{MATERIALS AND METHODS}

Plant material. Sweet orange trees with characteristic symptoms of HLB appeared in February 2007 in orchards of two municipalities of northern SPs: Barretos and Colômbia, hitherto free of HLB. By September 2007, HLB-affected trees had been found in 14 additional municipalities of which nine were in northern SPs, three in central SPs, and two in southern SPs (Fig. 1, Table 1). A total of 117 leaf samples with characteristic symptoms of blotchy mottle were collected on HLB-affected sweet orange trees from February to September 2007 in 23 citrus farms from the previous 16 municipalities. Thirty leaf samples were also collected from symptomless trees adjacent to the HLB-affected trees. Leaves from healthy sweet orange trees were from the greenhouse of Instituto Agronômico de Cordeirópolis (IAC), and were used as negative controls. Blotchy mottle leaves infected with ' $C a$. L. americanus' or ' $C a$. L. asiaticus' were from HLBcontrol trees in the greenhouse of Fundecitrus in Araraquara, SP, and served as the positive control. Leaves from periwinkle plants infected with the Picris echiödes yellows (PEY) phytoplasma (16Sr IX), as well as periwinkle and lime leaves infected with the lime witches'-broom phytoplasma ('Candidatus Phytoplasma aurantifolia', 16Sr II), were from the Bordeaux laboratory greenhouse, and served as positive controls for phytoplasmas.

Green, lopsided, sweet orange fruits, about $5 \mathrm{~cm}$ in diameter, from 20 HLB-affected trees, and normal fruits of the same size from 19 adjacent symptomless trees were collected in five citrus farms in the Barretos, Colômbia, José Bonifacio, Nova Granada, and Pedranopolis municipalities. Lopsided fruits infected with ' $C a$. L. americanus' or ' $\mathrm{Ca}$. L. asiaticus' were from HLB-control trees in the Fundecitrus greenhouse in Araraquara. Only the columellae were used for DNA extraction. Fruits were handled aseptically under a hood, and carefully cut in half through the columella, from the peduncular end down to the stylar end. Only lopsided fruits showing after sectioning aborted seeds, and conspicuous brownish-stained vascular bundles at the peduncular end of the longitudinally sectioned columellae, were used. From each half fruit, the peduncular portion of the columella tissue, which contained the brownish vascular bundles, was collected with the help of a scalpel under sterile conditions.

Extraction of DNA from leaves and fruit columellae. DNA extraction was from $500 \mathrm{mg}$ of leaf midribs as well as from columella tissue from three to four fruits, grinding the plant material with a Homex 6 homogenizer (Bio-Rad), and using the cetyl trimethyl ammonium bromide (CTAB) method (26). Prior to

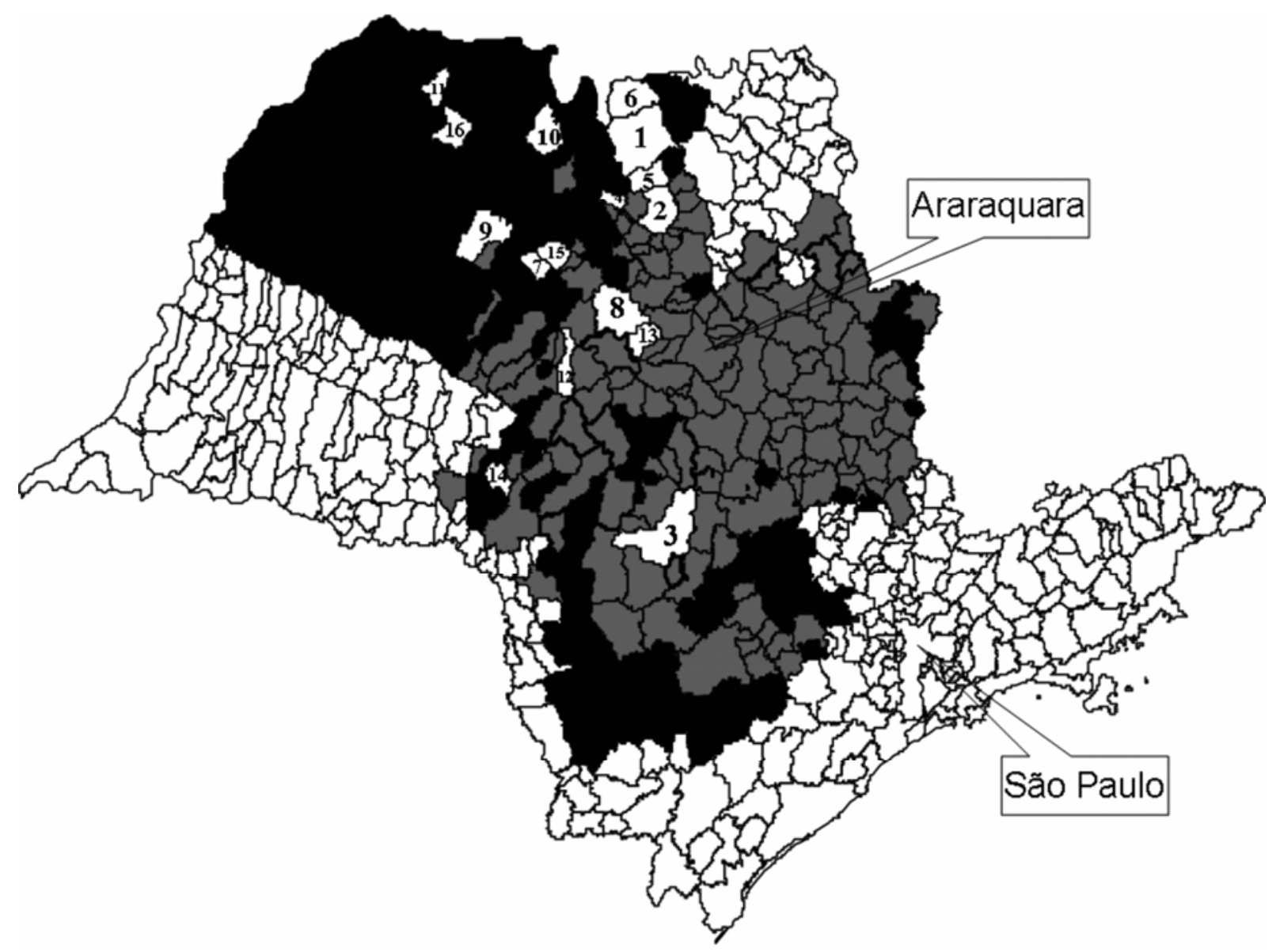

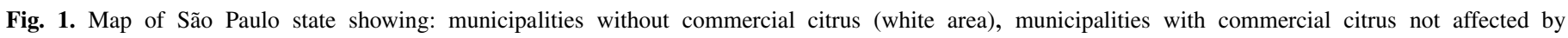
huanglongbing (HLB) (black area), affected by liberibacter-associated HLB (gray area), and phytoplasma-associated HLB (n). 
DNA extraction, the columella tissues were incubated for $4 \mathrm{~h}$ at

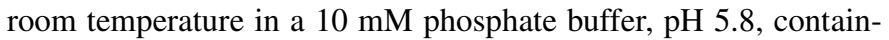
ing $0.16 \mathrm{~g}$ of macerozyme (Sigma) per $100 \mathrm{ml}$. The final pellet was resuspended in $100 \mu \mathrm{l}$ of sterile water.

Polymerase chain reaction (PCR) mixture. In all cases, PCR reactions were carried out in $40 \mu \mathrm{l}$ of reaction mixture containing: $500 \mathrm{ng}$ of template DNA from leaf midribs or fruit columellae, $4 \mu \mathrm{l}$ of $10 \times$ reaction buffer, $2 \mathrm{mM} \mathrm{MgCl}_{2}, 0.2 \mathrm{mM}$ of each dNTP, $500 \mathrm{nM}$ of each primer, and 1.25 units of Taq DNA polymerase (Invitrogen).

PCR amplification of bacterial 16S rDNA and sequence analysis. The method used was essentially that described previously for leaves $(22,34,35)$ and was based on amplification of prokaryotic ribosomal $16 \mathrm{~S}$ rRNA gene with universal primers fD1/rP1 (37). DNA extracted from symptomatic and symptomless leaf and columella samples were restricted with $B c l$ I to enhance amplification of bacterial $16 \mathrm{~S}$ rDNA. After amplification, the presence of amplified bacterial $16 \mathrm{~S}$ rDNA in addition to amplified mitochondrial and chloroplast $16 \mathrm{~S}$ rDNA, was ascertained with EcoRI, which cuts bacterial 16SrDNA in two fragments $(\approx 650$ and $\approx 850 \mathrm{bp}$ ), but has no action on plant $16 \mathrm{~S}$ rDNA (39). Amplification was for 35 cycles, each cycle being $60 \mathrm{~s}$ at $92^{\circ} \mathrm{C}, 60 \mathrm{~s}$ at $50^{\circ} \mathrm{C}$, and $90 \mathrm{~s}$ at $72^{\circ} \mathrm{C}$. The amplified DNA $(\approx 1,500 \mathrm{bp})$, checked for the presence of bacterial $16 \mathrm{~S}$ rDNA by the EcoRI test, was cloned, using the pGEM-T easy vector with the supplier's protocol (Promega.). Two microliters of the ligation mixture was used to transform E. coli electrocompetent cells (Bio-Rad). The cloned DNA was sequenced (BigDye chemistry, Applied Biosystems) in the laboratory of Escola Superior de Agricultura Luiz de Queiroz-Esalq-Departamento de Ciências Biológicas-Universidade São Paulo.

PCR protocols using universal phytoplasma primers: Amplifications of DNA from symptomatic columella. Amplification with primers fU5/rU3 (28) was as follows: an initial denaturation step of $4 \mathrm{~min}$ at $94^{\circ} \mathrm{C}$ followed by 40 cycles, each at $92^{\circ} \mathrm{C}$ for $45 \mathrm{~s}, 55^{\circ} \mathrm{C}$ for $45 \mathrm{~s}$, and $72^{\circ} \mathrm{C}$ for $45 \mathrm{~s}$, and a final $7 \mathrm{~min}$ extension step at $72^{\circ} \mathrm{C}$. The $3^{\prime}$ half of the $16 \mathrm{~S}$ rDNA followed by the complete ribosomal intergenic region (RIR) was obtained by PCR amplification with forward primer fU5 and reverse primer
P7 (30). Conditions for amplification were as follows: an initial step at $94^{\circ} \mathrm{C}$ for $4 \mathrm{~min}, 38$ cycles, each at $92^{\circ} \mathrm{C}$ for $45 \mathrm{~s}, 55^{\circ} \mathrm{C}$ for $45 \mathrm{~s}$, and $72^{\circ} \mathrm{C}$ for $90 \mathrm{~s}$, with a final step of $72^{\circ} \mathrm{C}$ for $7 \mathrm{~min}$.

For nested PCR, conditions were as follows: the first amplification was with primers P1/P7 (30). PCR conditions were initial denaturation of $4 \mathrm{~min}$ at $94^{\circ} \mathrm{C}$, followed by 35 cycles of $45 \mathrm{~s}$ denaturation at $92^{\circ} \mathrm{C}, 45 \mathrm{~s}$ annealing at $58^{\circ} \mathrm{C}, 90 \mathrm{~s}$ extension at $72^{\circ} \mathrm{C}$, and a final extension of $7 \mathrm{~min}$ at $72^{\circ} \mathrm{C}$. One microliter of reaction mixture was used for amplification with fU5/rU3 in the conditions indicated above.

Amplifications of DNA from symptomatic leaves. PCR with primers fU5/rU3 or nested PCR with primers P1/P7 followed by primers fU5/rU3 were also used for amplification of $16 \mathrm{~S}$ rDNA from blotchy mottle leaf DNA, with the conditions for amplification being the same than those for columella DNA amplification. The PCR products were purified using the Wizard SV Gel and PCR Clean-Up System (Promega) and sequenced as indicated previously.

PCR protocols using primers designed from the 16S rDNA gene sequence of the phytoplasma associated with citrus HLB symptoms (HLB-associated phytoplasma). Forward primer D7f2 (5'ATGTGTAGCTGGACTGAGAGG3') and reverse primer D7r2 (5'CTAAAGTGCTCACCATTACGTGG3') were used to detect the phytoplasma by amplification of a 16SrDNA sequence of $857 \mathrm{bp}$. The reaction was performed with the following program: an initial step at $94^{\circ} \mathrm{C}$ for $3 \mathrm{~min}$, followed by 35 cycles, each at $92^{\circ} \mathrm{C}$ for $45 \mathrm{~s}, 62^{\circ} \mathrm{C}$ for $45 \mathrm{~s}$, and $72^{\circ} \mathrm{C}$ for $45 \mathrm{~s}$ with a final step at $72^{\circ} \mathrm{C}$ for $7 \mathrm{~min}$.

Duplex PCR for detection of ' $\boldsymbol{C a}$. $\mathrm{L}$. asiaticus' and ' $\boldsymbol{C a}$. $\mathrm{L}$. americanus'. The detection involved a duplex PCR reaction with 16S rDNA primers GB1/GB3 for ' $C a$. L. americanus' $(33,34)$ and ribosomal protein primers A2/J5 for ' $\mathrm{Ca}$. L. asiaticus' (21). Amplification was for 35 cycles at $92^{\circ} \mathrm{C}$ for $45 \mathrm{~s}, 62^{\circ} \mathrm{C}$ for $45 \mathrm{~s}$, $72^{\circ} \mathrm{C}$ for $45 \mathrm{~s}$, with a final step at $72^{\circ} \mathrm{C}$ for $7 \mathrm{~min}$.

PCR detection of Spiroplasma citri. Amplification was performed with primer Sc1 (5'-ATT TTC AAT TTG ATG TTT ATC AAG ACA AC-3') and primer Sc1' (5'-CAA AAT CAC TTG CTC CTG CAT TTG G-3') designed from the spiralin gene sequence as described previously (27).

TABLE 1. Detection of the American liberibacter (Am), the Asian liberibacter (As), and the huanglongbing (HLB)-associated phytoplasma in 30 samples with symptomless leaves and 117 samples with blotchy mottle leaves from 16 municipalities of São Paulo state

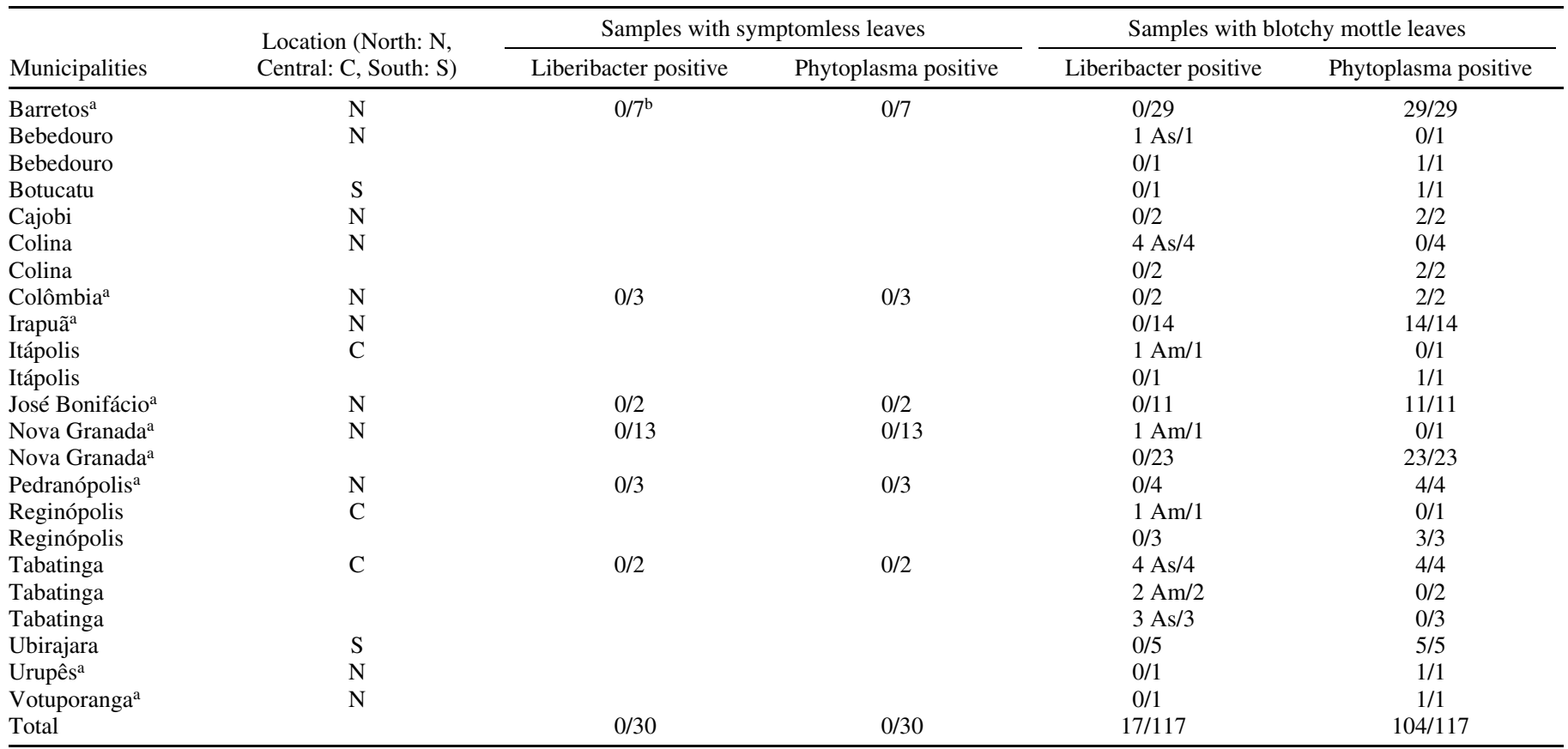

a Municipalities with no HLB-affected trees in 2006.

b Number of positive samples over total number of samples. 
Sequence analyses. Search for homologies in general databases was carried out using the BLAST algorithm (1). Multiple sequence alignments were performed using MULTALIN (8) or ClustalW (36) softwares.

16S rDNA phylogeny and sequence comparisons. Phylogenetic and molecular evolutionary analyses were conducted using MEGA version 4 (32). The bacterial 16S rDNA sequences used for comparisons were obtained from the GenBank database.

Electron microscopy detection of the HLB-associated phytoplasma in leaf midribs. Small pieces of midribs from symptomatic Pera sweet orange leaves from different origins in SPs, were fixed in a mixture of $2.5 \%$ glutaraldehyde and $2 \%$ paraformaldehyde in $0.05 \mathrm{M}, \mathrm{pH} 7.2$ cacodylate buffer for 2 to $3 \mathrm{~h}$, post-fixed in $1 \%$ osmium tetroxide in the same buffer, dehydrated in acetone, and embedded in the Spurr low viscosity epoxy resin (25). Longitudinal or transverse sections of the vascular region were made in a Leica EM U6 microtome equipped with a Diatome diamond knife, and the sections were stained with $3 \%$ uranyl acetate and Reynold's lead citrate before being examined in a Zeiss EM 900 transmission electron microscope. Five midrib samples from healthy greenhouse maintained 'Pera' sweet orange seedlings were processed as a negative control.

Distribution of the HLB-associated phytoplasma within citrus orchards of northern SPs. Data collected from two farms in Colômbia and Nova Granada municipalities were used for a preliminary and descriptive analysis of spatial distribution of phytoplasma-associated HLB-affected trees. The number of affected blocks and affected trees per block were recorded, and the position of the affected trees was marked. Since the maximum number of affected trees per block was very low (there were only 8 of 88 affected blocks with more than 10 affected trees), the usual spatial statistical analysis was not applied to describe the disease spatial distribution. Instead, the nearest distance between affected trees in each block was measured.

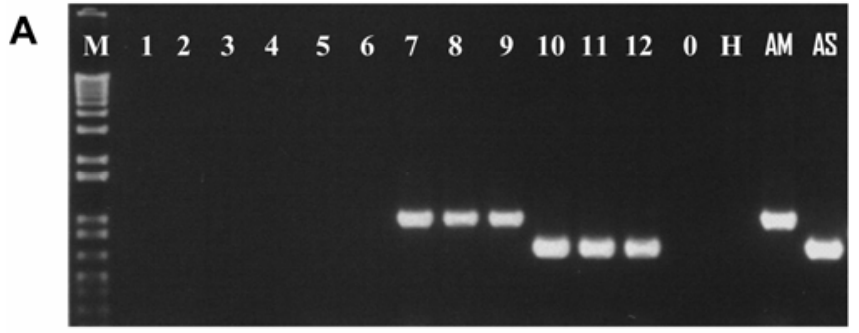

B

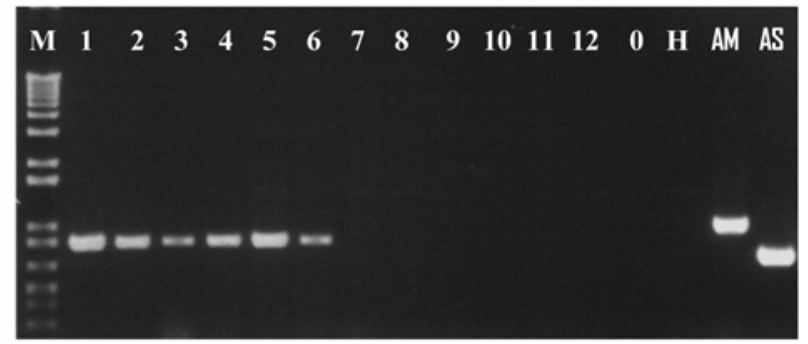

Fig. 2. A, Electrophoresis on $1 \%$ agarose gel of $16 \mathrm{~S}$ rDNA amplified by duplex polymerase chain reaction with primers GB1/GB3 for 'Candidatus $\mathrm{L}$. americanus' and A2/J5 for ' $\mathrm{Ca}$. L. asiaticus' from DNA extracted from blotchy mottle leaf samples collected in the following municipalities: Nova Granada (lane 1), Pedranopolis (lane 2), and Barretos (lanes 3, 4, 5, and 6) in northern São Paulo state, and Matão (lanes 7, 8, 9, and 10) and Araraquara (lanes 11 and 12) in central São Paulo state. Samples 7, 8, and 9 were known to be infected with ' $C a$. L. americanus', and samples 10,11 , and 12 , with ' $C a$. L. asiaticus'. Blotchy mottle leaf samples 1 to 6 from northern São Paulo state tested negative for liberibacters. B, Same as in A, except that primers used were D72/D7r2 for amplification of the 16S rDNA of the huanglongbing (HLB)-associated phytoplasma. No amplification was obtained with liberibacters. Am, As, Ph, and M: DNA amplified from control leaves infected with 'Ca. L. americanus', 'Ca. L. asiaticus', and the HLB-associated phytoplasma, respectively.

\section{RESULTS}

Search for a new bacterial agent in HLB-affected trees in northern SPs. While many municipalities in central and southern SPs have become affected by HLB since 2004, the northern part of the state was still free of the disease in 2006. However, in February 2007, sweet orange trees with typical branch, leaf, and fruit symptoms of HLB were seen for the first time in the municipalities of Barretos and Colômbia in northern SPs. When leaves with blotchy mottle symptoms, characteristic of HLB, were collected on such trees and analyzed for the presence of ' $\mathrm{Ca}$. L. americanus' and/or ' $\mathrm{Ca}$. L. asiaticus' by duplex PCR with specific primers GB1/GB3+A2/J5, all PCR reactions were negative (Fig. $2 \mathrm{~A}$, tracks 1 to 6 ), under conditions where control leaves, infected with either one of the two liberibacters, gave positive reactions (Fig. 2A, tracks 7 to 12). Since some of the symptoms of citrus "stubborn", a disease caused by the helical mollicute Spiroplasma citri (6), are somewhat similar to those of HLB, the symptomatic leaves from northern SPs were also tested with $S$. citri-specific primers. No evidence for the presence of $S$. citri could be found (data not shown). These results suggested that the HLB leaves from northern SPs were probably infected with a new agent, giving no PCR amplifications with liberibacter- or spiroplasmaspecific primers. The presence of a putative bacterium in the blotchy mottle leaves from Barretos and Colômbia was investigated by trying to amplify the $16 \mathrm{~S}$ rDNA of the putative bacterium with universal primers $\mathrm{fD} 1 / \mathrm{rP} 1$ for bacterial $16 \mathrm{~S}$ rDNA (37). Several blotchy mottle leaf DNA samples were analyzed in this way. With some leaf DNA samples, no amplification of bacterial 16SrDNA occurred. With other samples, amplification did occur, but the bacterium identified after sequencing of its 16SrDNA and BLAST search, differed from one DNA sample to the other. The following bacteria were identified from the various leaf DNA sample used: Massilia timonae, (generally isolated from environment and human patients), Pseudomonas saccharophila (a soil bacterium), Nevskia ramosa (bacterium growing on the surface of aquatic systems), Terribacillus saccharophilus (a soil bacterium), and Sphingomonas phyllosphaerae (isolated from the phyllosphere of Acacia caven). None of these bacteria were consistently associated with blotchy mottle leaf samples. They appeared to be bacteria which happened to be present on the surface or in the apoplast of the leaves used for analysis.

To avoid such bacteria, it was thought that internal fruit tissues, essentially sterile, might be a better source of plant material. Indeed, HLB-affected sweet oranges are lopsided, have aborted seeds, and their vascular bundles at the peduncular end of the columella are brownish. In the case of liberibacter-associated HLB, electron microscopy has shown the phloem sieve tubes of these bundles to contain liberibacters. Therefore, columella tissue from symptomatic fruits was collected aseptically, used for DNA extraction, and the resulting columella DNA preparation served as target DNA for amplification with the universal primers fD1/rP1, as was done previously with leaf DNA preparations. Next, the amplified DNA was submitted to the EcoRI treatment to detect the presence of bacterial 16S rDNA in the amplified DNA. Figure 3 shows that, indeed, the EcoRI test was positive since two clearcut DNA restriction fragments of the expected sizes $(\approx 650$ and $850 \mathrm{bp}$ ) were obtained, not only with amplified DNA corresponding to control columellae infected with ' $\mathrm{Ca}$. L. americanus' (Fig. 3), but also with amplified DNA corresponding to two of three samples of symptomatic columellae from northern SPs (DNA sample $3 \mathrm{c}$ from Colômbia municipality and $5 \mathrm{c}$ from Barretos municipality). With PCR products from healthy columellae, samples 1c from Barretos municipality and 2c from Colômbia municipality, the two EcoRI fragments of bacterial origin were not obtained. Thus, the experiment of Figure 3 suggested that the symptomatic columellae of sample $3 \mathrm{c}$ and $5 \mathrm{c}$ contained a bac- 
terial agent, which was not present in the healthy columellae of samples $1 \mathrm{c}$ and $2 \mathrm{c}$.

The 1,500 bp DNA amplified from sample 3c, contained not only the bacterial $16 \mathrm{~S}$ rDNA, but also the chloroplast $16 \mathrm{~S}$ rDNA. It was cloned to recover the bacterial $16 \mathrm{~S}$ rDNA free of chloroplast DNA. In total, 63 clones were obtained of which one clone had a plasmid insert sensitive to EcoRI restriction, characteristic of bacterial 16S rDNA (data not shown). This clone was selected, named D7, and its insert was sequenced (accession no. EU266074).

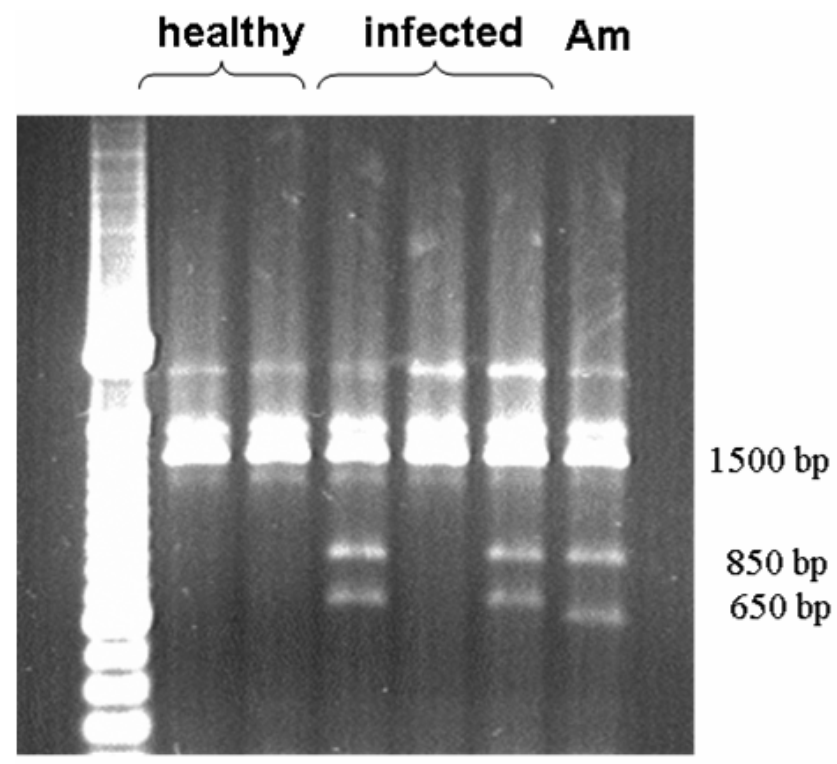

\section{1c 2c 3c 4c 5c 6c}

Fig. 3. Electrophoresis on $1 \%$ agarose gel of DNA treated with EcoRI after amplification with primers $\mathrm{fD} 1 / \mathrm{rP} 1$ from $\mathrm{Bcl}$-1-treated DNA extracted from healthy $(\mathrm{H})$ sweet orange columellae (1c and 2c), columellae from lopsided (I), huanglongbing (HLB)-affected sweet orange fruits $(3 \mathrm{c}, 4 \mathrm{c}, 5 \mathrm{c})$ from northern São Paulo state and testing negative for Liberibacters, and control columellae (6c) from lopsided fruits testing positive for 'Candidatus Liberibacter americanus' (Am) DNA preparations from sweet orange columellae amplified with universal.
The sequence was 1,494-bp long and was bordered, as expected, by the sequences of primers fD1 and rP1 (Fig. 4). Sequence analysis showed the 1,494-bp DNA fragment of clone D7 to be $16 \mathrm{~S}$ rDNA and to share $99 \%$ sequence identity with pigeon pea witches'-broom phytoplasma 16S rDNA (accession no. AF248957), 98\% with Lactuca serriola phytoplasma 16S rDNA (accession no. AF515638), and 97\% with almond witches'-broom phytoplasma 16S rDNA (accession no. AF455041), these three phytoplasmas being members of phytoplasma (16Sr IX) group. Sequence identity with the $16 \mathrm{~S}$ rDNA of Candidatus Phytoplasma aurantifolia, the lime witches'-broom phytoplasma of group $16 \mathrm{Sr}$ II (accession no. EF186828), was only 91\%. These results suggested that a phytoplasma of group 16Sr IX, with $99 \% 16 \mathrm{~S}$ rDNA sequence identity with the pigeon pea witches'-broom phytoplasma, was present in the columellae of sample $3 \mathrm{c}$ from Colômbia municipality.

Amplifications of ribosomal DNA with universal phytoplasma primers. With phytoplasmas now in the forefront, it became clear that universal phytoplasma primers should be used: fU5/rU3 and P1/P7. Primers fU5/rU3 were used to amplify $16 \mathrm{~S}$ rDNA from the following four DNA samples: (i) columella sample $3 \mathrm{c}$ from Colômbia municipality, used previously and having led to the phytoplasma identification, (ii) columella sample 5c, from Barretos municipality, (iii) columella sample F4, from José Bonifacio municipality, and (iv) leaf sample 9,240, from Pedranopolis municipality. The four PCR products were sequenced. The four sequences comprised 735 bp of $16 \mathrm{~S}$ rDNA (Fig. 4) and shared $100 \%$ sequence identity. Their unique sequence was identical to the corresponding sequence of the 1,494-bp DNA fragment (Fig. 4).

The DNAs from columella samples $3 c$ and $5 c$ were amplified with fU5 and P7 (Fig. 4) to gain access to the 16S/23S ribosomal intergenic region (RIR). The two fU5/P7 amplicons were sequenced. They had identical sequences. As shown on Figure 4, the unique sequence of $1,394 \mathrm{bp}$ contained $1,154 \mathrm{bp}$ of $16 \mathrm{~S}$ rDNA at the $5^{\prime}$ end, and the entire $236 \mathrm{bp}$ (RIR) plus $4 \mathrm{bp}$ of $23 \mathrm{~S}$ rDNA at the $3^{\prime}$ end. The 1,124-bp sequence of $16 \mathrm{~S}$ rDNA was identical to the corresponding sequences of the following two DNAs: (i) the 1,494-bp DNA of clone D7 from sample 3c, and (ii), the 735-bp DNA amplified with primers fU5/rU3 from three columella samples and one leaf sample (previously listed). These sequence

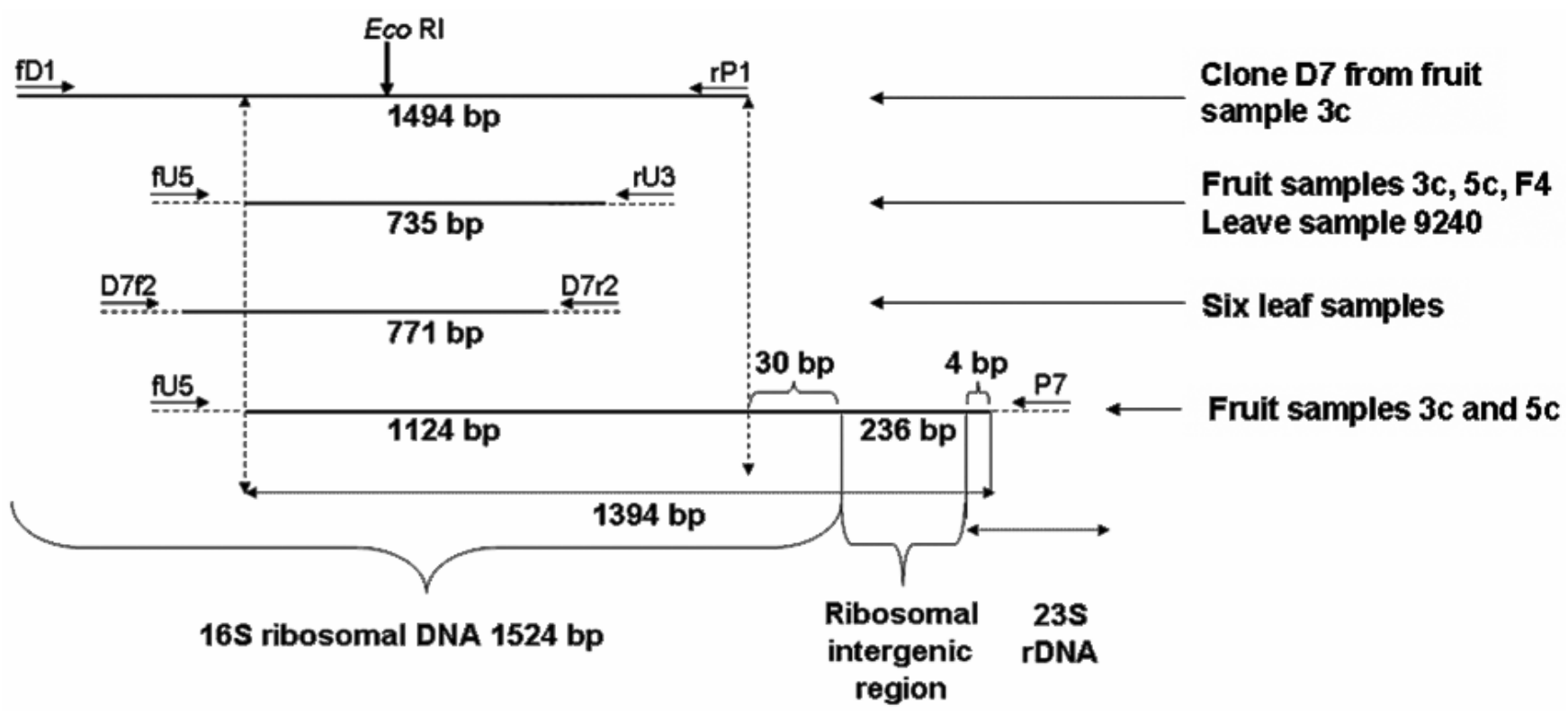

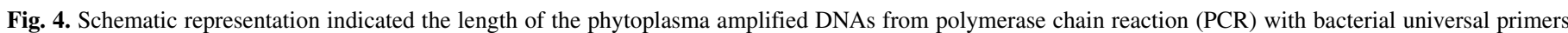

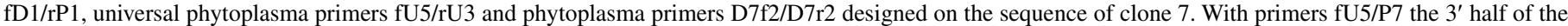

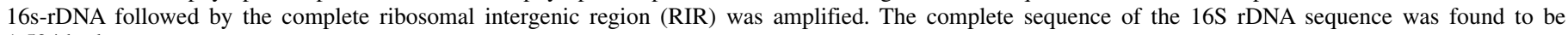
1,524 bp long. 
identities indicated that the 236-bp RIR sequence belonged to the same ribosomal operon as the $16 \mathrm{~S}$ rDNA sequences. In summary, based on the sequence analysis of the 1,494-bp sequence obtained with primers $\mathrm{fD} 1 / \mathrm{rP} 1$, the 735 -bp sequence obtained with primers $\mathrm{fU} 5 / \mathrm{rU} 3$, and the 1,394-bp sequence obtained with primers fU5/P7, it was determined that the complete 16S rDNA sequence was $1,524 \mathrm{bp}$ and was followed by a 236-bp RIR, totaling 1,760-bp sequence. When this 1,760-bp sequence was used for BLAST search, the pigeon pea witches'-broom phytoplasma again showed the highest sequence identity: $99 \%$, followed by the Lactuca serriola phytoplasma (98\%) and the almond witches'-broom phytoplasma from Lebanon, 'Candidatus Phytoplasma phoenicium' (accession no. AF616637) (97\%), all three being members of group 16Sr IX.

Further evidence from 16S rDNA sequence for a phytoplasma of group 16Sr IX to be associated with HLB symptoms in SPs. Primers D7f2/D7r2 were designed from the 1,524-bp 16S rDNA sequence of the citrus phytoplasma and used to amplify DNA preparations from six samples of blotchy mottle leaves from five municipalities: Cajobi (sample no. 10630), Votuporanga (sample no. 10708), Reginópolis (samples no. 9672 and 10303), Bebedouro (sample no. 9450), and Urupês (sample no. 9806). The six PCR products were purified and sequenced. They had identical sequences, and the unique $16 \mathrm{~S}$ rDNA sequence of $771 \mathrm{bp}$ had $100 \%$ sequence identity with the corresponding 16S rDNA sequences of the 1,494-, 735-, and 1,394-bp DNAs of Figure 4.

Identical phytoplasma $16 \mathrm{~S}$ rDNA sequences were amplified from three columella samples and seven leaf samples from nine different municipalities of SPs (Fig. 4). All samples came from sweet orange trees showing characteristic HLB symptoms and testing negative for liberibacters. The corresponding citrus phytoplasma, associated with characteristic HLB symptoms, and abbreviated hereafter as "HLB-associated phytoplasma" has $99 \%$ $16 \mathrm{~S}$ rDNA+RIR sequence identity with the pigeon pea witches'broom phytoplasma of group 16Sr IX. Figure 5 shows the position of the HLB-associated phytoplasma on the 16SrDNA phylogenetic tree of group 16Sr IX phytoplasmas.

Detection of the HLB-associated phytoplasma in 16 municipalities of SPs. While Figure 2A shows that duplex PCR with primers GB1/GB3 for ' $C a$. L. americanus' and primers A2/J5 for ' $\mathrm{Ca}$. L. asiaticus' detects the two liberibacters but not the phytoplasma, Figure 2B illustrates the fact that PCR with primers D7f2/D7r2 is able to detect the phytoplasma, but not the liberibacters. For phytoplasma detection, nested PCR with primers $\mathrm{P} 1 / \mathrm{P} 7$ followed by primers fU5/rU3, yields the same results as PCR with primers D7f2/D7r2, but is more sensitive (data not shown). The PCR and the nested PCR for detection of the phytoplasma, as well as the duplex PCR for detection of the liberibacters, have been applied to the 117 blotchy mottle leaf samples and the 30 leaf samples from symptomless trees of Table 1 . The 117 symptomatic leaf samples included the seven leaf samples of Figure 4 . None of the 30 symptomless leaf samples tested positive, neither for liberibacters nor for phytoplasmas. The 117 symptomatic samples came mainly from municipalities in northern SPs, where most of the phytoplasma-infected trees had been

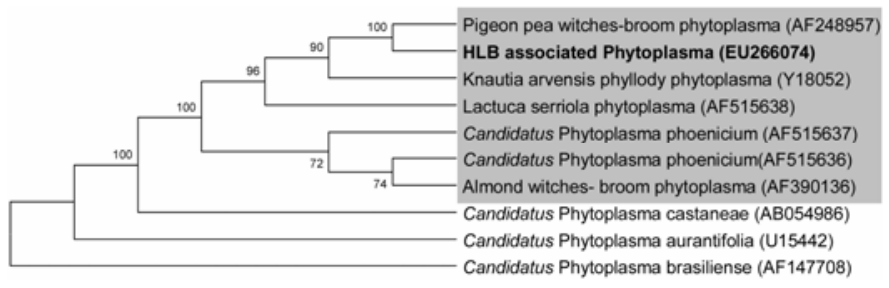

Fig. 5. Phylogenetic tree inferred from $16 \mathrm{~S}$ rDNA sequences using the maximum parsimony method. The percentage of replicate trees in which the associated taxa clustered together in the bootstrap test (500 replicates) is shown next to the branches. found, but some were also from central and southern SPs. The phytoplasma was detected in 104 of the 117 samples, (Table 1) and ' $\mathrm{Ca}$. L. americanus' or ' $\mathrm{Ca}$. L. asiaticus' in 17 of the 117 samples. Four samples from Tabatinga municipality, were infected with both the phytoplasma and ' $\mathrm{Ca}$. L. asiaticus', whereas the other samples testing positive for the phytoplasma were negative for the liberibacters, and vice-versa. The northern SPs municipalities were most likely free of HLB at the time when the HLB-associated phytoplasma was detected. By September 2007, they contained $85(82 \%)$ of the 104 phytoplasma positive samples, with the remaining samples being from central and southern SPs municipalities.

Finally, the phytoplasma was also detected in 10 of 20 symptomatic fruit samples tested, including samples 3c, 5c, and F4, which were used initially to obtain the $16 \mathrm{~S}$ rDNA sequence of the phytoplasma (Fig. 4). All 19 symptomless fruit samples tested negative.

Detection of the HLB-associated phytoplasma by electron microscopy. Twenty-four leaf midrib samples were examined by electron microscopy to confirm the presence of the phytoplasma in the sieve tubes in PCR positive material from different localities: Pedranópolis (one sample), Barretos (nine samples), Nova Granada (seven samples), and Irapuã (seven samples). Only a small number of phytoplasma-like bodies were found in a few sieve tubes, in four samples from Nova Granada and two from Barretos, either in cross sections or longitudinal sections. Similarly, in the case of liberibacter-associated HLB in SPs, the number of liberibacter cells in sieve tubes was also small. The phytoplasma structures were elliptical in shape (200 to 1,000 nm) and surrounded by a single unit membrane (Fig. 6). These results are in contrast with usual phytoplasma infections where large numbers of cells could be seen in most of the sieve tubes. No Liberibacter-like bacterial cells were found in the phytoplasmapositive samples. Phytoplasma-like bodies were not found in the sieve tubes of leaf midribs from five negative control samples.

Distribution of phytoplasma-infected trees within sweet orange orchards of northern SPs. In September 2007, the incidence of phytoplasma-associated HLB sweet orange trees in northern SPs was still low. Even though in the selected farms, many citrus blocks were affected (20 blocks in Colômbia municipality and 68 in Nova Granada municipality), the number of phytoplasma-associated HLB-affected trees per block was small: 1 to 23 (average: 3.4 trees per block), with only eight blocks with more than 10 affected trees. It represents a disease incidence in the block ranging from 0.01 to $1.76 \%$ with an average of $0.14 \%$. Within $90 \%$ of the blocks, the affected trees were distributed randomly, with some aggregation being observed only in larger spatial scales and in higher disease incidences $(>20$ affected trees). Only one of 88 affected blocks had affected trees side by side, one focus with two contiguous trees, and one focus with three adjacent trees. In $80 \%$ of cases the minimum distances between affected trees were higher than $100 \mathrm{~m}$.
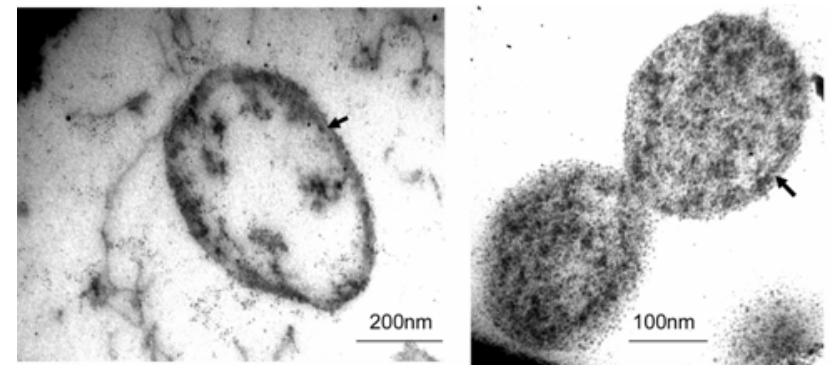

Fig. 6. Electron micrograph of huanglongbing-associated phytoplasma cells in sieve tube of polymerase chain reaction positive midribs. The cytoplasmic membrane surrounding the cells is indicated by arrows. 


\section{DISCUSSION}

The 16S rDNA of the HLB-associated phytoplasma could be successfully amplified with universal bacterial primers fD1/rP1 from DNA preparations of symptomatic columella tissues but not from those of symptomatic leaf midribs. Contrary to leaf midribs, columella came from the inner part of the fruit, an environment essentially free of exogenous bacteria, as opposed to endogenous bacteria restricted to the sieve tubes or the xylem vessel (5). Thus, in the DNA preparations from symptomatic fruit columellae, $16 \mathrm{~S}$ rDNA from the endogenous phytoplasma would be the only bacterial DNA to be recognized by, and amplified with, primers fD1/rP1. However, chloroplast and mitochondrial 16S rDNA from the host plant were also amplified. Hence, after amplification with $\mathrm{fD} 1 / \mathrm{rP} 1$, the phytoplasmal $16 \mathrm{~S}$ rDNA has to be cloned before it can be sequenced. Of 63 clones, only one clone had a phytoplasmal DNA insert. When universal phytoplasma primer fU5/P7 or fU5/rU3 was used, a positive amplification reaction occurred not only with DNA preparations from symptomatic fruit columellae, but also with those from leaf midribs. No amplification of DNA preparations from liberibacter-infected tissues or from symptomless leaves with or without exogenous bacteria was observed. Hence, when positive PCR reactions with these primers were obtained from symptomatic fruit columellae or leaf midribs, the amplicons corresponded in every case to phytoplasmal 16S rDNA, and they could be sequenced directly after a simple purification, without the need for cloning.

On the basis of the $16 \mathrm{~S}$ rDNA sequence and the sequence of the $16 \mathrm{~S} / 23 \mathrm{~S}$ RIR, only one type of phytoplasma was detected. Indeed, according to the primers used, the following 16S rDNA sequences were amplified from DNA preparations of blotchy mottle leaf midribs and lopsided-fruit columellae, which were sampled on HLB-affected sweet orange trees: (i) the 1,494-bp sequence from one columella sample (3c), using primers fD1/rP1, (ii) the $735 \mathrm{bp}$ sequence from each of three columella samples (3c, 5c, and F4) and one leaf sample $(9,240)$, using primers fU5/rU3, (iii) the 771-bp sequence from each of six leaf midrib samples, the primers used being D7f2/D7r2, and (iv) the 1,394-bp sequence from each of two columellae samples (3c and 5c), using primers fU5/P7. These 13 16S rDNA sequences from three different columellae samples and seven different leaf midrib samples, collected in nine different municipalities of SPs, shared $100 \%$ sequence identities. The unique 16S rDNA sequence corresponded to a phytoplasma of group 16Sr IX, having 99\% 16S rDNA+ 16/23 RIR sequence identity with the pigeon pea witches'-broom phytoplasma. Interestingly, phytoplasmas of group $16 \mathrm{Sr}$ IX have already been detected in Brazil in Catharanthus roseus collected at Recife, PE (2), as well as at Piracicaba in SPs (3).

The phytoplasma of group 16Sr IX was associated with HLB for the following reasons. (i) The phytoplasma was detected in a total of 104 leaf samples and 10 fruit columellae samples from 16 municipalities. These samples, without exception, came from sweet orange trees showing HLB symptoms indistinguishable from those associated with liberibacters. The leaves sampled showed characteristic blotchy mottle symptoms and the columellae sampled came from lopsided sweet orange fruits with aborted seeds and brownish-stained vascular bundles. (ii) The 30 leaf samples and the 19 fruit samples from symptomless trees, most often adjacent to the HLB-affected trees, gave negative PCR reactions for the phytoplasma not only with single PCR but nested PCR as well, and they also tested negative for liberibacters. Thus, in SPs, three agents are associated with HLB symptoms: two alpha-proteobacteria (' $\mathrm{Ca}$. L. americanus' and ' $\mathrm{Ca}$. L. asiaticus') and one phytoplasma (phytoplasma of group 16Sr IX). Citrus is not the only host in which identical symptoms are produced by a proteobacterium and a phytoplasma. Marginal chlorosis of strawberries in France is associated with (i) 'Candidatus Phlomobacter fragariae', a gamma-proteobacterium, trans- mitted by the cixiid planthopper Cixius wagneri in production fields, and (ii) the stolbur phytoplasma, transmitted by Hyalesthes obsoletus in nurseries (11). Similarly, in Burgundy, France, the syndrome "Basses Richesses" of sugar beet is associated with a gamma-proteobacterium closely related to Candidatus Phlomobacter fragariae, and the stolbur phytoplasma, both transmitted by the cixiid planthopper Pentastiridius sp. The two agents are associated with the same symptoms on sugar beet $(16,29)$. In Australia, strawberry lethal yellows is associated with (i) two phytoplasmas: 'Candidatus Phytoplasma australiense' and the tomato big bud phytoplasma, and (ii) a "rickettsia-like-organism (RLO), and it is difficult to differentiate the symptoms associated with the RLO from those associated with phytoplasmas $(18,31)$. Sieve tube-restricted mollicutes are involved in two other diseases of citrus: stubborn disease, due to Spiroplasma citri $(5,6)$, and witches'-broom disease of lime (Citrus aurantifolia), associated with 'Candidatus Phytoplasma aurantifolia' (group 16Sr II) (5). Even though the general aspect of sweet orange trees affected by stubborn disease is very different from that of HLB-affected trees, fruit symptoms of stubborn resemble those of HLB and include lopsidedness, aborted seeds, and brownish vascular bundles in the columella. In lime trees, the symptoms associated with ' $\mathrm{Ca}$. P. aurantifolia' are very different from those associated with the HLB phytoplasma.

In SPs, the HLB-associated phytoplasma has very probably been transmitted to citrus from an external source of inoculum, but the putative insect vector is not yet known. It could be a leafhopper, a planthopper, or even a psyllid. However, from the distribution of most phytoplasma-associated HLB-affected trees within citrus blocks, no secondary infections, from citrus to citrus, seem to have occurred, and therefore, D. citri, the citrus psyllid which transmits the liberibacters from citrus to citrus, is probably not involved in phytoplasma transmission at this moment. While the first phytoplasma-associated HLB trees were found in the municipalities of Barretos and Colômbia in northern SPs, phytoplasma-infected trees have now been detected also in central and even southern SPs. This observation seems to indicate that the external source of inoculum on which the putative vector becomes infected is relatively well distributed throughout SPs. It could be a weed or a crop plant. For instance, legume plants such as Cajanus sp. or Crotalaria sp. are used as cover crop plants in the sugar cane industry, have a wide distribution in SPs, and could be candidate host plants of the phytoplasma.

Until now, control of liberibacter-associated HLB in SPs was based on (i) removal of the sources of inoculum, i.e., liberibacterinfected citrus trees and the ornamental citrus relative Murraya paniculata (jasmine orange), and (ii) control of D. citri by insecticide treatments. As the psyllid vector is a monophagous insect, feeding only on citrus and jasmine orange, insecticide sprays could, so far, be limited to these plants. If, however, the insect vector of the HLB-associated phytoplasma turns out to be polyphagous, its control by insecticide sprays might be much more difficult than that of the $D$. citri, unless the major source of inoculum is a crop plant, which could eventually be replaced by one resistant to the phytoplasma and not used as a host by the vector.

From the results presented here, it cannot be assessed whether the HLB-associated phytoplasma is a new member of phytoplasma group 16Sr IX or a strain of a known phytoplasma. Before an answer can be given, genes less conserved than ribosomal genes must become available for sequence comparisons and the development of PCR primers highly specific to HLB-associated phytoplasma. With the primers used in this work, there are no difficulties to detect the phytoplasma in citrus trees. Based on the results of this study, only one phytoplasma is present. However, detection of the HLB-associated phytoplasma in insects, for vector identification, might be more complicated because other group 16Sr IX phytoplasmas might give positive PCR reactions with the available phytoplasma primers. 


\section{ACKNOWLEDGMENTS}

We thank A. G. Mariano and A. P. R. Leite for excellent technical help.

\section{LITERATURE CITED}

1. Altschul, S. F., Madden, T. L., Schäffer, A. A., Zhang, J. H., Zhang, Z., Miller, W., and Lipman, D. J. 1997. Gapped BLAST and PSI-BLAST: A new generation of protein database search programs. Nucleic Acids Res. 25:3389-3402.

2. Barros, T. S. L. 2002. Page 107 in: Caracterização molecular de Mollicutes fitopatogênicos no Brasil. Ph.D. thesis, University of Brasília, Brazil.

3. Bedendo, I. P., Davis, R. E., and Dally, L. 1999. Detecção e caracterização de fitoplasmas em plantas de vinca (Catharanthus roseus) e de pimenta (Capsicum frutescens) através de técnicas de duplo PCR e RFLP. (Abstr.) Summa Phytopathol. 25:197-201.

4. Bové, J. M. 2006. Huanglongbing: A destructive, newly-emerging, century-old disease of citrus. J. Plant Pathol. 88:7-37.

5. Bové, J. M., and Garnier, M. 2002. Phloem- and xylem-restricted plant pathogenic bacteria. Plant Sci. 163:1083-1098.

6. Bové, J. M., Renaudin, J., Saillard, C., Foissac, X., and Garnier, M. 2003. Spiroplasma citri, a plant pathogenic mollicute: Relationships with its two hosts, the plant and the leafhopper vector. Annu. Rev. Phytopathol. 41:483-500.

7. Coletta-Filho, H. D., Targon, M. L. P. N., Takita, M. A., De Negri, J. D., Pompeu, J. J., and Machado, M. A. 2004. First report of the causal agent of huanglongbing ("Candidatus Liberibacter asiaticus") in Brazil. Plant Dis. $88: 1382$.

8. Corpet, F. 1988. Multiple sequence alignment with hierarchical clustering. Nucleic Acids Res. 16:10881-10890.

9. Da Graça, J. V. 1991. Citrus greening disease. Annu. Rev. Phytopathol. 29:109-136.

10. Da Graça, J. V., and Korsten, L. 2004. Citrus huanglongbing: Review, present status and future strategies. Pages 229-245 in: Diseases of Fruits and Vegetables. S. A. M. H. Naqvi, ed. Kluwer Academic Publishers, Dordrecht, The Netherlands.

11. Danet, J.-L., Foissac, X., Zreik, L., Salar, P., and Verdin, E. 2003. "Candidatus Phlomobacter fragariae" is the prevalent agent of marginal chlorosis of strawberry in French production fields and is transmitted by the planthopper Cixius wagneri (China). Phytopathology 93:644-649.

12. Garnier, M., and Bové, J. M. 1996. Distribution of the huanglongbing (greening) liberibacter species in fifteen African and Asian countries. Pages 388-391 in: Proceedings of 13th Conference IOCV, Riverside, CA.

13. Garnier, M., and Bové, J. M. 2000. Huanglongbing in Cambodia, Laos, and Myanmar. Pages 378-380 in: Proceedings of 14th Conference IOCV, Riverside, CA.

14. Garnier, M., Bové, J. M., Cronje, C. P. R., Sanders, G. M., Korsten, L., and Le Roux, H. F. 2000 Presence of "Candidatus Liberibacter africanus" in the Western Cape province of South Africa. Pages 369-372 in: Proceedings of 14th Conference IOCV, Riverside, CA.

15. Garnier, M., Jagoueix, S., Toorawa, P., Grisoni, M., Mallessard, R., Dookun, A., Saumtally, S., Autrey, J. C., and Bové, J. M. 1996. Both huanglongbing (greening) liberibacter species are present in Mauritius and Reunion. Pages 392-394 in: Proceedings of 13th Conference IOCV, Riverside, CA.

16. Gatineau, F., Jacob, N., Vautrin, S., Larue, J., Lherminier, J., RichardMolard, M., and Boudon-Padieu, E. 2002. Association with the syndrome "Basses richesses" of sugar beet of a phytoplasma and a bacterium-like organism transmitted by a Pentastiridius sp. Phytopathology 92:384-392.

17. Gottwald, T. R., da Graça, J. V., and Bassanezi, R. B. 2007. Citrus huanglongbing: The pathogen and its impact. Plant Health Progress Online publication DOI:10.1094/PHP-0906-01-RV.

18. Greber, R. S., and Gowanlock, D. H. 1979. Rickettsia-like and mycoplasma-like organisms associated with two yellow-type diseases of strawberries in Queensland. Aust. J. Agric. Res. 30:1101-1109.

19. Halbert, S. E., and Manjunath, K. L. 2004. Asian citrus psyllids (Sternorrhycha: Psyllidae) and greening disease of citrus: A literature review and assessment of risk in Florida. Fla. Entomol. 87:330-353.

20. Halbert, S. E., and Nuñez, C. A. 2004. Distribution of the Asian citrus psyllid, Diaphorina citri Kuwayama (Rhynchota: Psyllidae) in the Caribbean basin. Fla. Entomol. 87:401-402.

21. Hocquellet, A., Toorawa, P., Bové, J. M., and Garnier, M. 1999. Detection and identification of the two "Candidatus Liberibacter sp." associated with citrus huanglongbing by PCR amplification of ribosomal protein genes of the beta operon. Mol. Cell. Probes 13:373-379.

22. Jagoueix, S., Bové, J. M., and Garnier, M. 1994. The phloem-limited bacterium of greening disease of citrus is a member of the $\alpha$ subdivision of the Proteobacteria. Int. J. Syst. Bacteriol. 44:397-386.

23. Jagoueix, S., Bové, J. M., and Garnier, M. 1996. PCR detection of the two 'Candidatus' liberibacter species associated with greening disease of citrus. Mol. Cell. Probes 10:43-50.

24. Jagoueix, S., Bové, J. M., and Garnier, M. 1997. Comparison of the 16S/23S Ribosomal Intergenic Regions of "Candidatus Liberibacter asiaticum" and "Candidatus Liberibacter africanum", the two species associated with citrus huanglongbing (greening) disease. Int. J. Syst. Bacteriol. 47:224-227.

25. Kitajima, E. W., and Nome, C. F. 1999. Microscopia eletrônica em virologia vegetal. Pages 59-87 in: Métodos para Detectar Patógenos Sistêmicos. D. M. Docampo and S. L. Lenardon, eds. Córdoba IFFYVE/ INTA, Spain.

26. Murray, M. G., and Thompson, W. F. 1980. Rapid isolation of high molecular weight plant DNA. Nucleic Acids Res. 8:4321-4325.

27. Najar, A., Bouachem, S., Danet, J. L., Saillard, C., Garnier, M., and Bové, J. M. 1998. Présence en Tunisie de Spiroplasma citri, l'agent causal du stubborn des agrumes et de son vecteur, la cicadelle Circulifer haematoceps. Contamination de $C$. haematoceps et $C$. opacipennis par $S$. citri. Fruits 53:391-396.

28. Seemüller, E., Schneider, B., Mäurer, R., Ahrens, U., Daire, X., Kison, H., Lorenz, K. H., Firrao, G., Avinent, L., and Sears, B. B. 1994. Phylogenetic classification of phytopathogenic mollicutes by sequence analyses of 16S ribosomal DNA. Int. J. Syst. Bacteriol. 44:440-446.

29. Sémétey, O., Gatineau, F., Bressan, A., and Boudon-Padieu, E. 2007. Characterization of a $\gamma-3$ proteobacteria responsible for the syndrome "Basses Richesses" of sugar beet transmitted by Pentostiridius sp. (Hemiptera, Cixiidae). Phytopathology 97:72-78.

30. Smart, C. D., Schneider, B., Blomquist, C. L., Guerra, L. J., Harrison, N. A., Ahrens, U., Lorentz, K. H., Seemüller, E., and Kirkpatrick, B. C. 1996. Phytoplasma-specific PCR primers based on sequences of the 16S23S rRNA spacer region. Appl. Environ. Microbiol. 62:2988-2993.

31. Streten, C., Waite, G. K., Herrington, M. E., Hutton, G. D., Persley, D. M., and Gibbs, K. S. 2005. Rickettsia-like-organisms and phytoplasmas associated with diseases in Australian strawberries. Australas. Plant Pathol. 34:157-164.

32. Tamura, K., Dudley, J., Nei, M., and Kumar, S. 2007. MEGA4: Molecular evolutionary genetics analysis (MEGA) software version 4.0. Mol. Biol. Evol. 24:1596-1599.

33. Teixeira, D. C., Danet, J. L., Eveillard, S., Martins, E. C., Jesus Junior, W. C. de, Yamamoto, P. T., Lopes, S. A., Bassanezi, R. B., Ayres, A. J., Saillard, C., and Bové, J. M. 2005. Citrus huanglongbing in São Paulo State, Brazil: PCR detection of the "Candidatus" Liberibacter species associated with the disease. Mol. Cell. Probes 19: 173-179.

34. Teixeira, D. C., Saillard, C., Eveillard, S., Danet, J. L., Ayres, A. J., and Bové, J. M. 2005. "Candidatus Liberibacter americanus", associated with citrus huanglongbing (greening disease) in São Paulo State, Brazil. Int. J. Syst. Evol. Microbiol. 55:1857-1862.

35. Teixeira, D. C., Saillard, C., Eveillard, S., Danet, J. L., Ayres, A. J., and Bové, J. M. 2005. A new liberibacter species, Candidatus Liberibacter americanus sp. nov., is associated with citrus huanglongbing (greening disease) in São Paulo State, Brazil. Pages 325-340 in: Proceedings16th Conference IOCV, Riverside, CA.

36. Thompson, J. D., Higgins, D. G., and Gibson, T. J. 1994. CLUSTAL W: Improving the sensitivity of progressive multiple sequence alignment through sequence weighting, position-specific gap penalties and weight matrix choice. Nucleic Acids Res. 22:4673-4680.

37. Weisburg, W. G., Barns, S. M., Pelletier, D. A., and Lane, D. J. 1991. 16S ribosomal DNA amplification for phylogenetic study. J. Bacteriol. 173:697-703.

38. Yamamoto, P. T., Felippe, M. R., Garbim, L. F., Coelho, J. H. C., Ximenes, N. L., Martins, E. C., Leite, A. P. R., Sousa, M. C., Abrahao, D. P., and Braz, J. D. 2006. Diaphorina citri (Kuwayama) (Hemiptera: Psyllidae): Vector of the bacterium Candidatus Liberibacter americanus. Page 96 in: Proc. of the Huanglongbing-Greening Intl. Workshop, Ribeirão Preto, SP, Brazil.

39. Zreik, L., Bové, J. M., and Garnier, M. 1998. Phylogenetic characterization of the bacterium-like organism associated with marginal chlorosis of strawberry and proposition of a Candidatus taxon for the organism Candidatus Phlomobacter fragariae. Int. J. Syst. Bacteriol. 48:257-261. 